\title{
Now all the world's a sage.
}

\section{De la Galaxia Marshall McLuhan a las Constelaciones de Susan Buck-Morss}

From the Marshall McLuhan Galaxy to the Susan Buck-Morss Constellations

\author{
GABRIEL MARTÍNEZ (10 0000-0002-2786-9641 \\ SONIA DÍAZ (1) 0000-0001-5602-6371
}

\section{Resumen}

Este ensayo visual está formado por una constelación de imágenes y palabras/imágenes obtenidas en las redes sociales. La lógica la proporciona el sistema digital y su formalización es fruto del uso redundante de la propia tecnología digital a través de programas de autoedición y publicación. Partimos de dos ideas: la primera afirma que la comunidad global es un collage/montaje de imágenes donde el medio es el masaje que crea un sistema de valores basado en las percepciones; y la segunda, señala que necesitamos abrir profundidad de campo y ralentizar nuestros actos perceptivos de forma que las imágenes permitan construir un lugar de acción política común. Nuestros guías han sido el filósofo y teórico Marshall McLuhan y la filósofa e historiadora intelectual Susan Buck-Morss.

PalABras Clave: Buck-Morss, McLuhan, Activismo, Activismo Socio-cultural.

Ensayo visual

Visual Essay

Correspondencia/ Correspondence Gabriel Martínez unmundofeliz@gmail.com

Financiación/Fundings Sin financiación

Received: 23.09.2020 Accepted: 20.12.2020

CÓMO CITAR ESTE TRABAJO / HOW TO CITE THIS PAPER

Martínez, G. (2020). Now all the world's a sage. De la Galaxia Marshall McLuhan a las Constelaciones de Susan Buck-Morss. Umática. Revista sobre Creación y Análisis de la Imagen, 3.

https://doi.org/10.24310/Umatica.2020.v2i3.11190

Umática. 2020; 3:243-264 


\section{Abstract}

This visual essay is composed of a constellation of images and words/images obtained from social networks. The logic is provided by the digital system and its formulation is the result of the redundant use of digital technology itself through desktop publishing and publishing programs. We proceed on the basis of two ideas: the first states that the global community is a collage/assembly of images where the medium is the massage that creates a value system based on perceptions; and the second states that we need to open up depth of field and slow down our perceptive acts so that the images allow us to build a common place of political action. Our guides have been the philosopher and theorist Marshall McLuhan and the philosopher and intellectual historian Susan Buck-Morss.

KEYWORDS: McLuhan, Buck-Morss, Activism, Socio-cultural Activism. 


\section{INTRO}

La cultura global excluye e incluye, es fría y caliente, local y global, privada y pública; y presenta razonamientos lineales por conexión y a saltos por intervalo, aunque lo más importante de nuestra cultura actual es que puede llegar a ser estúpida pero nunca aburrida. El diseño y las prácticas artísticas contemporáneas exigen rapidez y emoción pero también persiguen una profundidad y reducen el ritmo de nuestra percepción aunque no nos demos cuenta. El espíritu humano más creativo siempre está buscando un espacio de acción política común (Buck-Morss, 2015) donde las imágenes circulen sin fronteras ni barreras, produzcan constelaciones imprevistas y sean accesibles proporcionando su potencial más democrático. Así, para Buck-Morss (2013), "la reorientación se convierte en la revolución de nuestro tiempo" y dicha reorientación significa una reutilización, revisión, reconexión e intercambio de imágenes donde las representaciones individuales pueden adquirir un efecto social y político. En este sentido, no nos interesa la evidencia-imagen o el prejuicio-imagen sino la posibilidad-imagen, su adecuación a la comunicación y su realidad significativa. No es tanto la búsqueda de una intencionalidad objetiva sino las conexiones resignificantes que huyen de la crítica tediosa que Marshall McLuhan desprecia al señalar que "Marx es un estúpido y aburrido escritor visual" (Sempere, 1975, p.175).

"Ahora todo el mundo es un sabio" porque "un niño de seis años de nuestra época sabe tanto como Matusalén" (Sempere, 1975, p.237). El continuo bombardeo de imágenes provoca una nueva educación perceptiva que nos masajea de forma continuada aportando conocimiento, dando información y desatando emociones y sentimientos. Por ello, una ética digital socializadora -no socialista- sólo es posible a partir del uso libre de las imágenes como un bien público. La idea de un conocimiento abierto y compartido como un recurso inagotable es un valor colectivo que nos promete sabiduría y mayor confianza pública. Tanto McLuhan en sus exploraciones como Buck-Morss con sus notas nos recuerdan que las imágenes se usan para pensar, que son una promesa de accesibilidad al conocimiento y nos permiten la conexión, el compromiso y la participación. Por lo tanto, apropiarse de una imagen es una experiencia sensorial vital, es aquella percepción que "proporciona la armadura para las ideas" (Buck-Morss, 2013).

Ahora todos somos sabios porque las imágenes que compartimos no son copias de un original sino que poseen una realidad propia que conecta y entra a formar parte de una constelación en red. Cada uno de nosotros como coleccionistas (no-consumidores) de imágenes armamos un collage/montaje/memoria que produce sentido y al compartirlas colectivamente ampliamos el proceso de construcción de la cultura. En este sentido, gracias a nuestras bibliotecas de imágenes, nos convertimos en investigadores marginales de nuestra realidad y formamos parte de una escuela-planeta global (Sempere 1975, p.154) cuya forma de cognición colectiva moldea una nueva imagen del mundo. 
Toda imagen se percibe como superficie, una percepción congelada que puede ser manipulada y activada para conseguir otra nueva imagen, percepción y significado. Los objetos físicos carecen de esta capacidad infinita de reproducción y resignificación compartida, sin embargo, "las imágenes son el archivo de la memoria colectiva" (Buck-Morss, 2013) porque pueden ser percibidas por todos y en cualquier momento. Las imágenes digitales siempre están fuera de contexto porque no pueden evitar adquirir nuevos significados y trasmitir potencia al visualizar los pasados, los presentes y los futuros. Las imágenes son multiplicadoras, unen lo singular y lo universal. Todos podemos observar las mismas imágenes y, sin embargo, la potencialidad de actuar sobre cada uno de nosotros es totalmente distinta e incontrolable. Su significado depende de la percepción personal y de la empatía colectiva, porque si somos realmente creativos nuestro sistema perceptivo estará en constante movimiento. 
Politics

- BEYOND THIS POINT YOU MAY ENCOUNTEF * * NUDE SUNBATHER
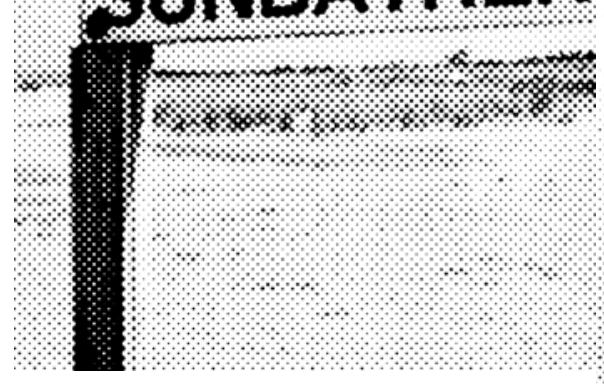

s
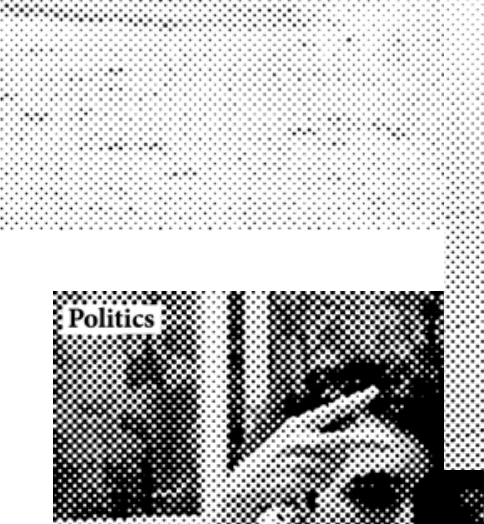

\&
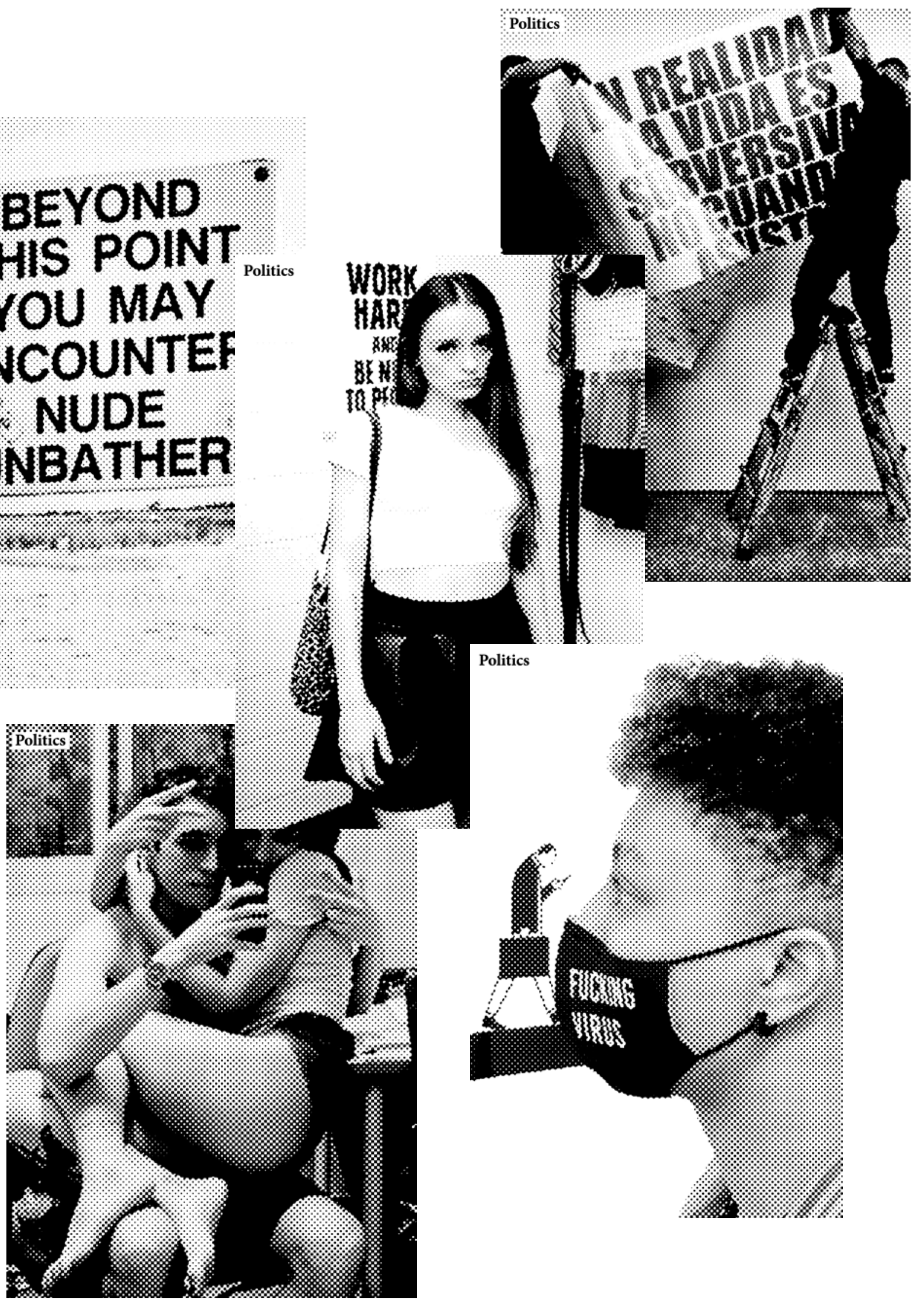
Politics
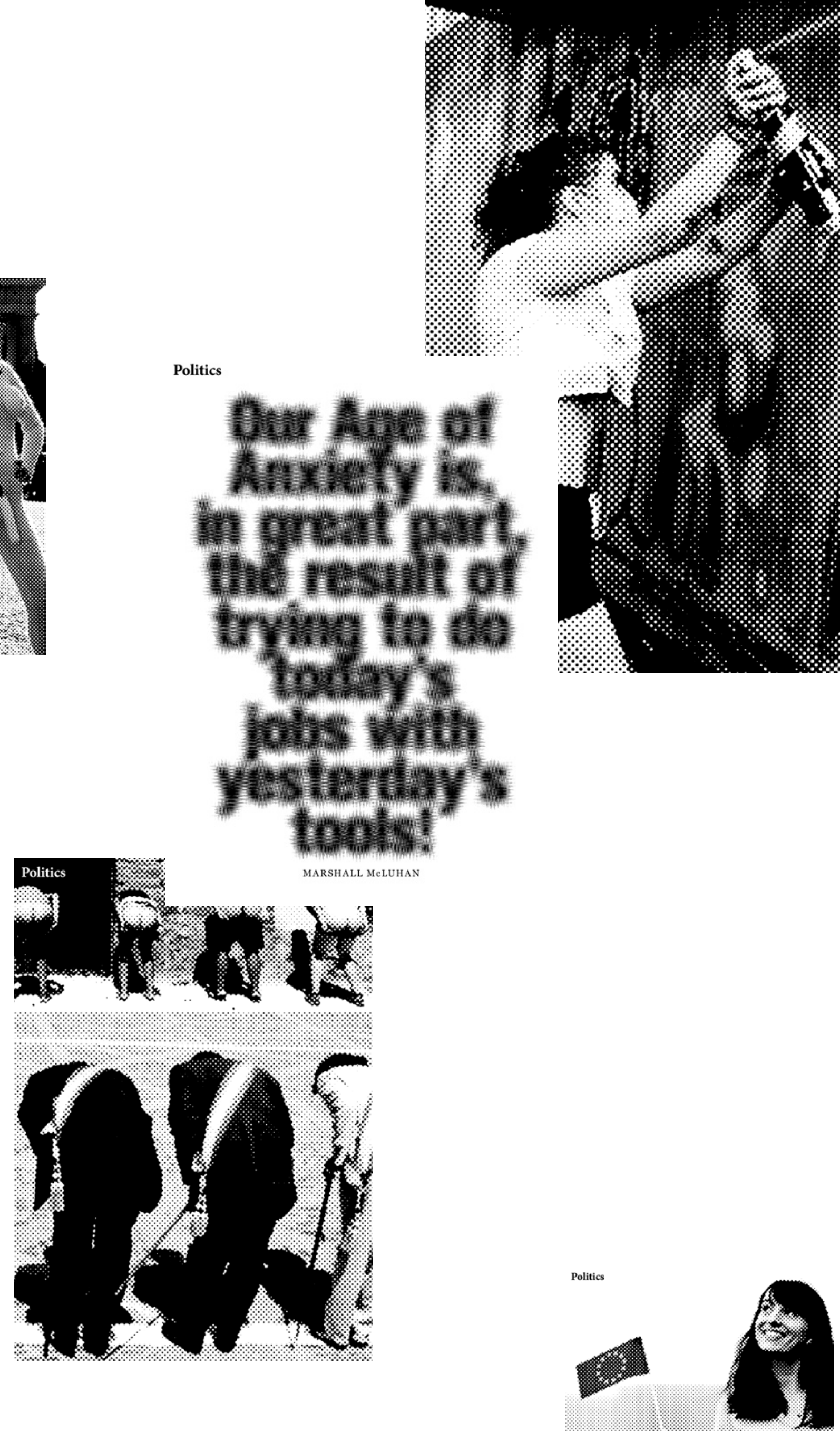


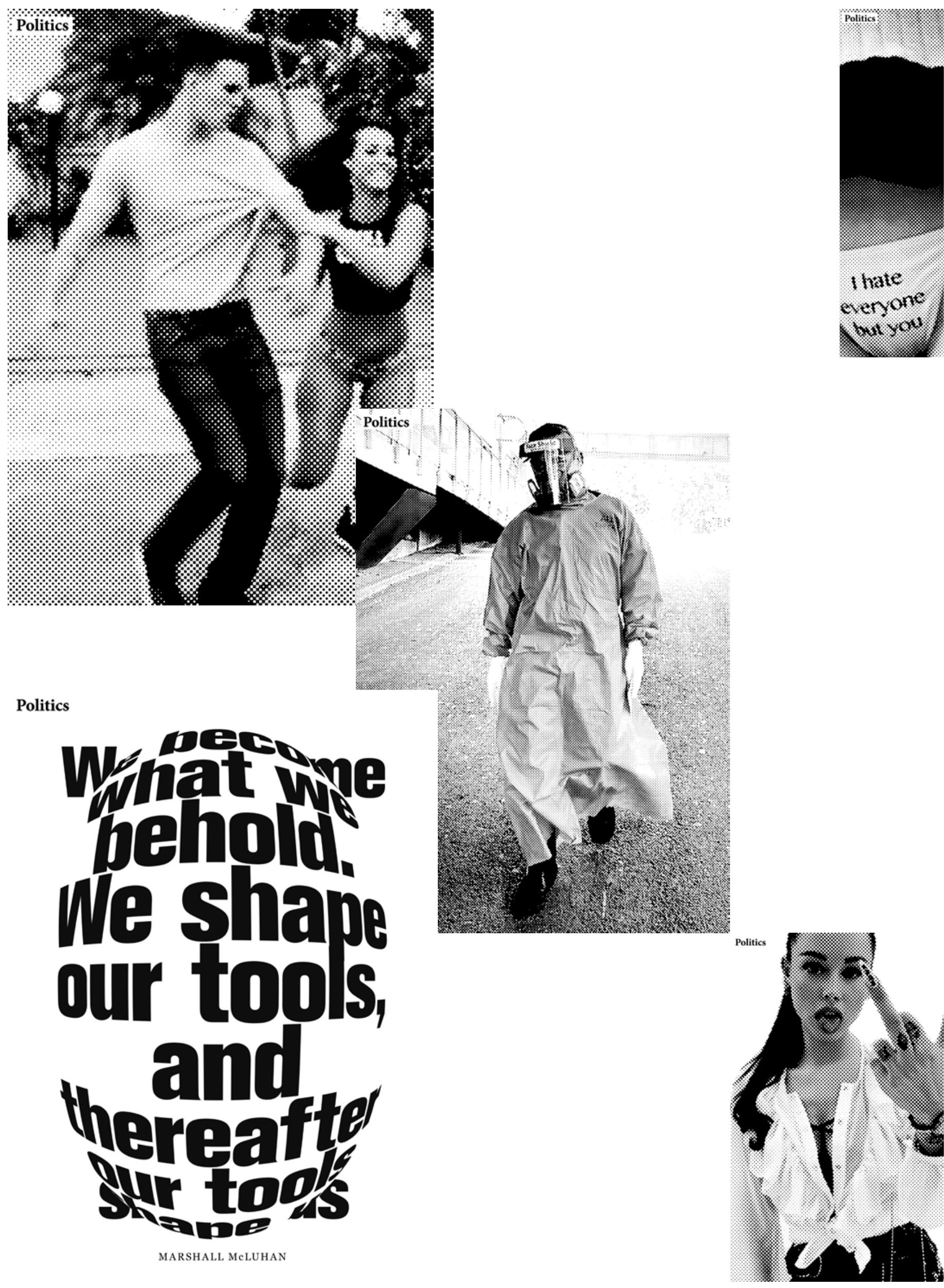



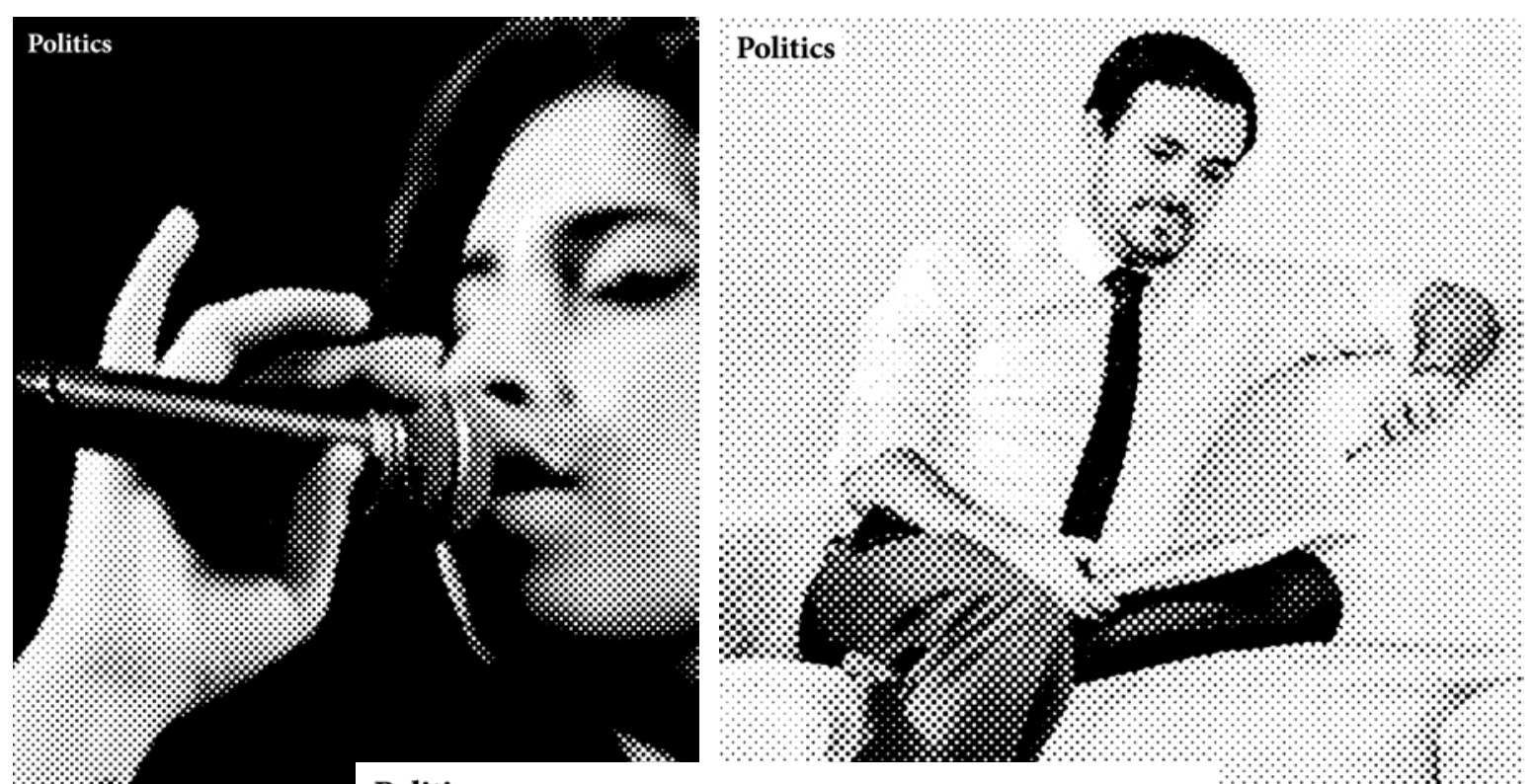

Politics

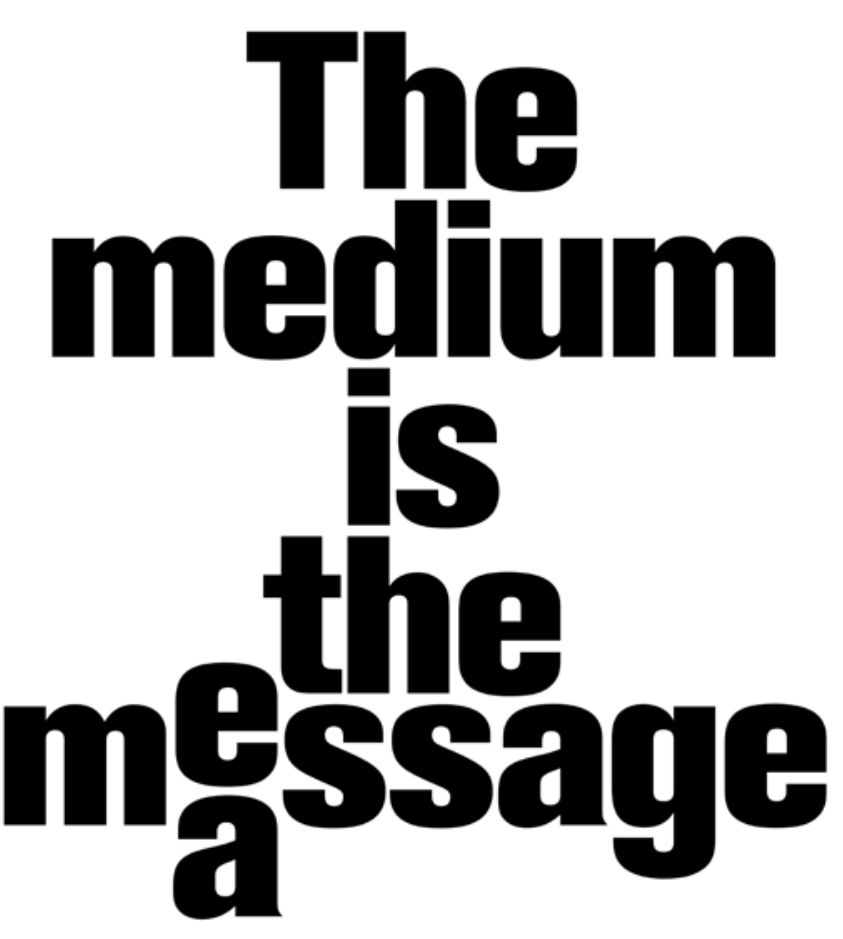

MARSHALL McLUHAN

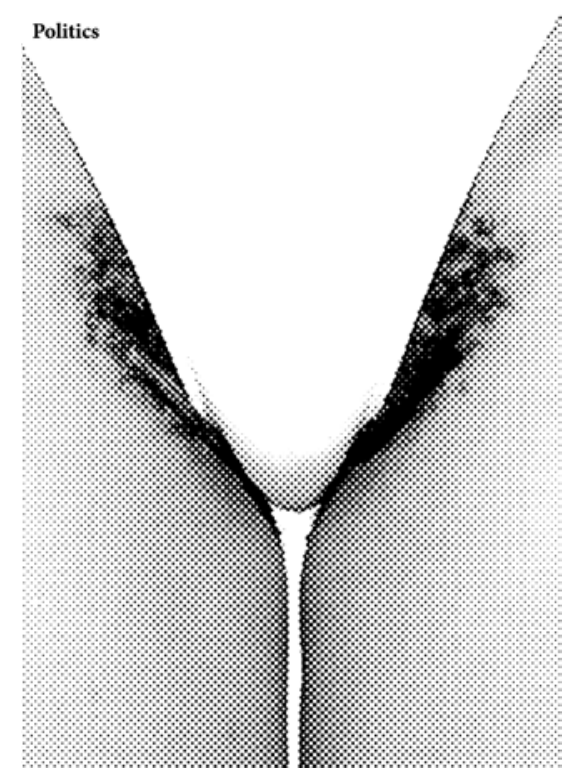


Politics
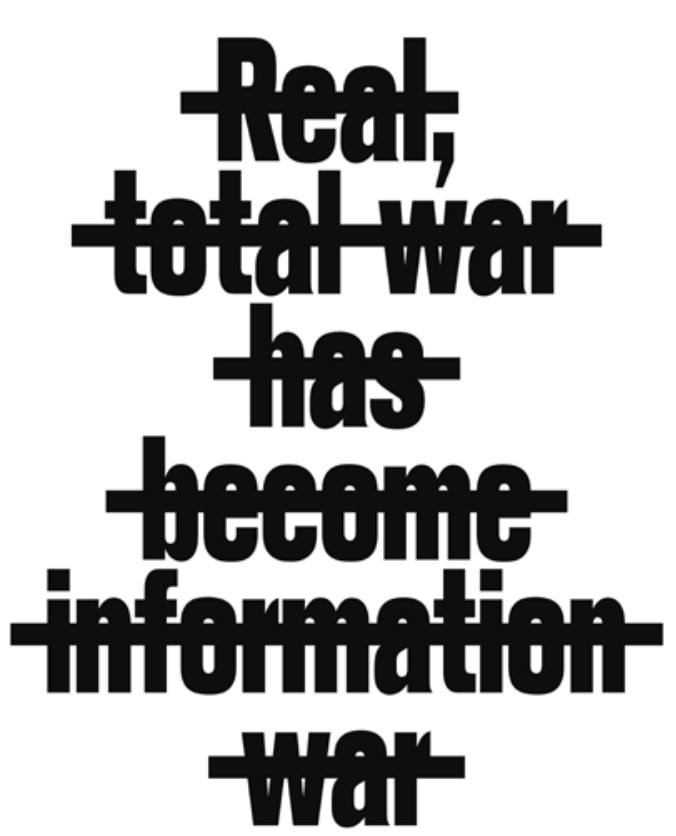

MARSHALL MeLUHAN
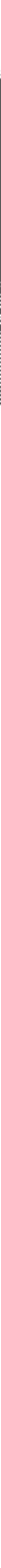

11 a revele la corruption, la crasse des etats. Naus ne devons aAs le lolsser en orison pour le reste de so vie Libort pour Jution Awsonge 
$42-8-216$
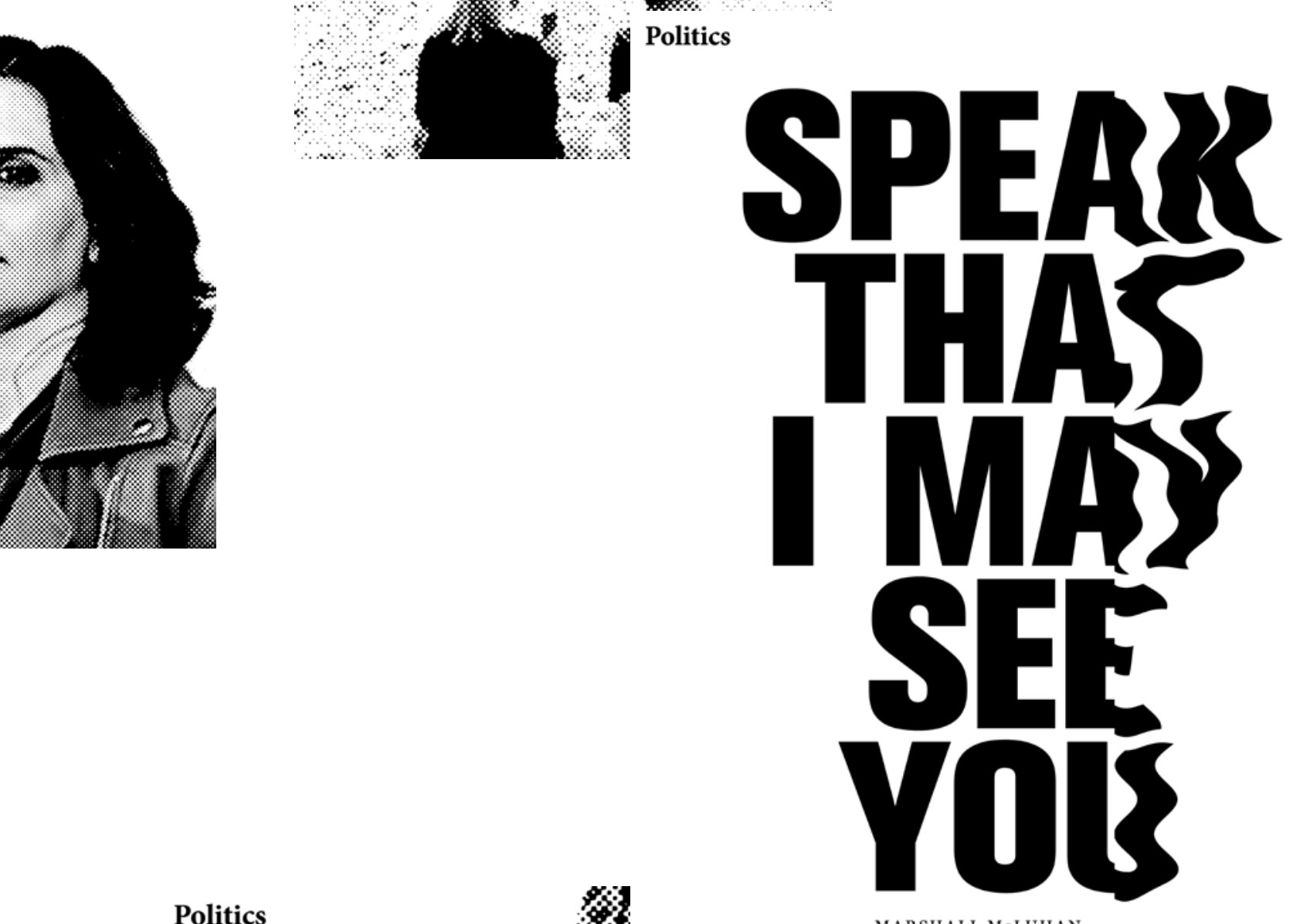

Politics
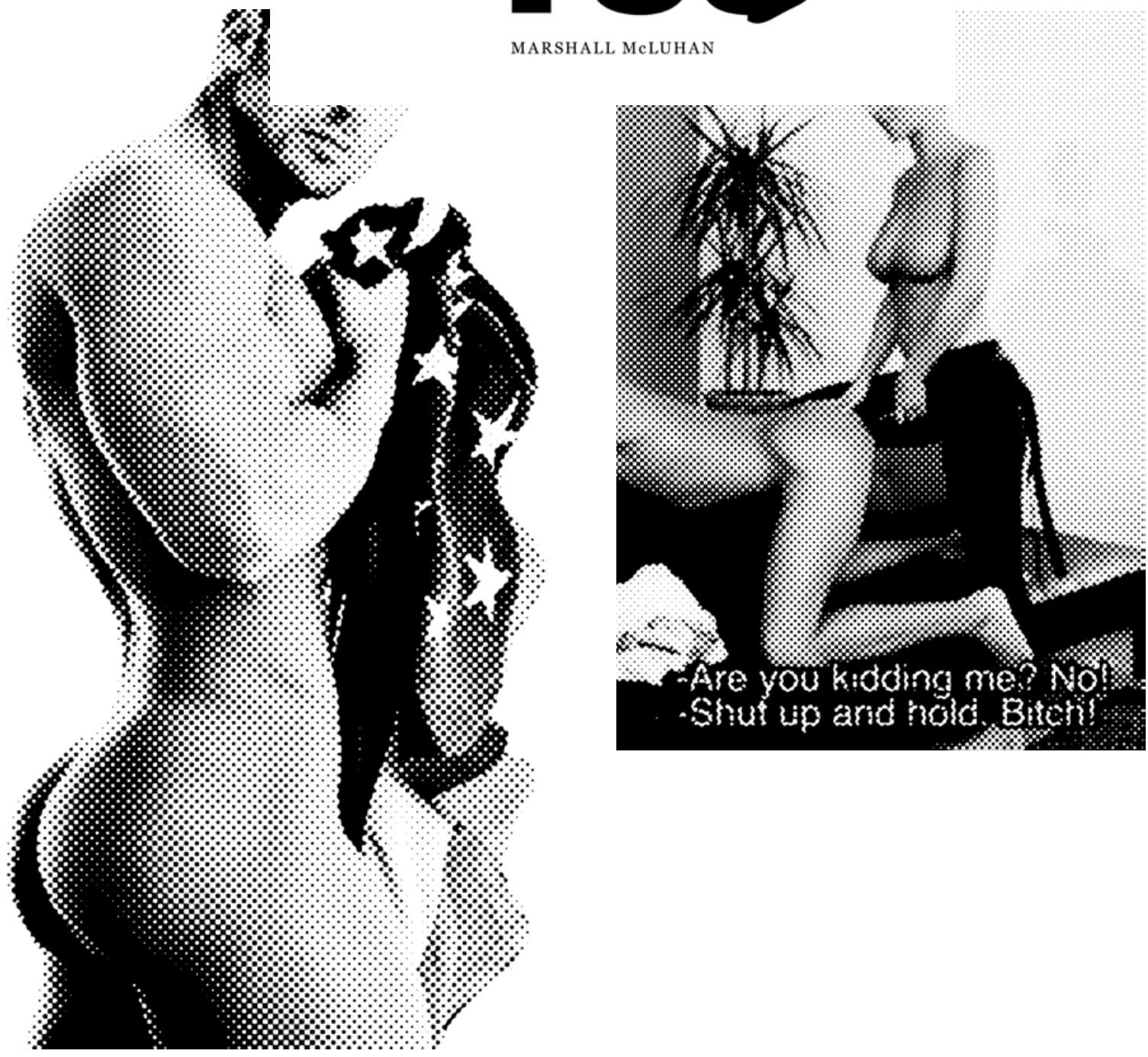


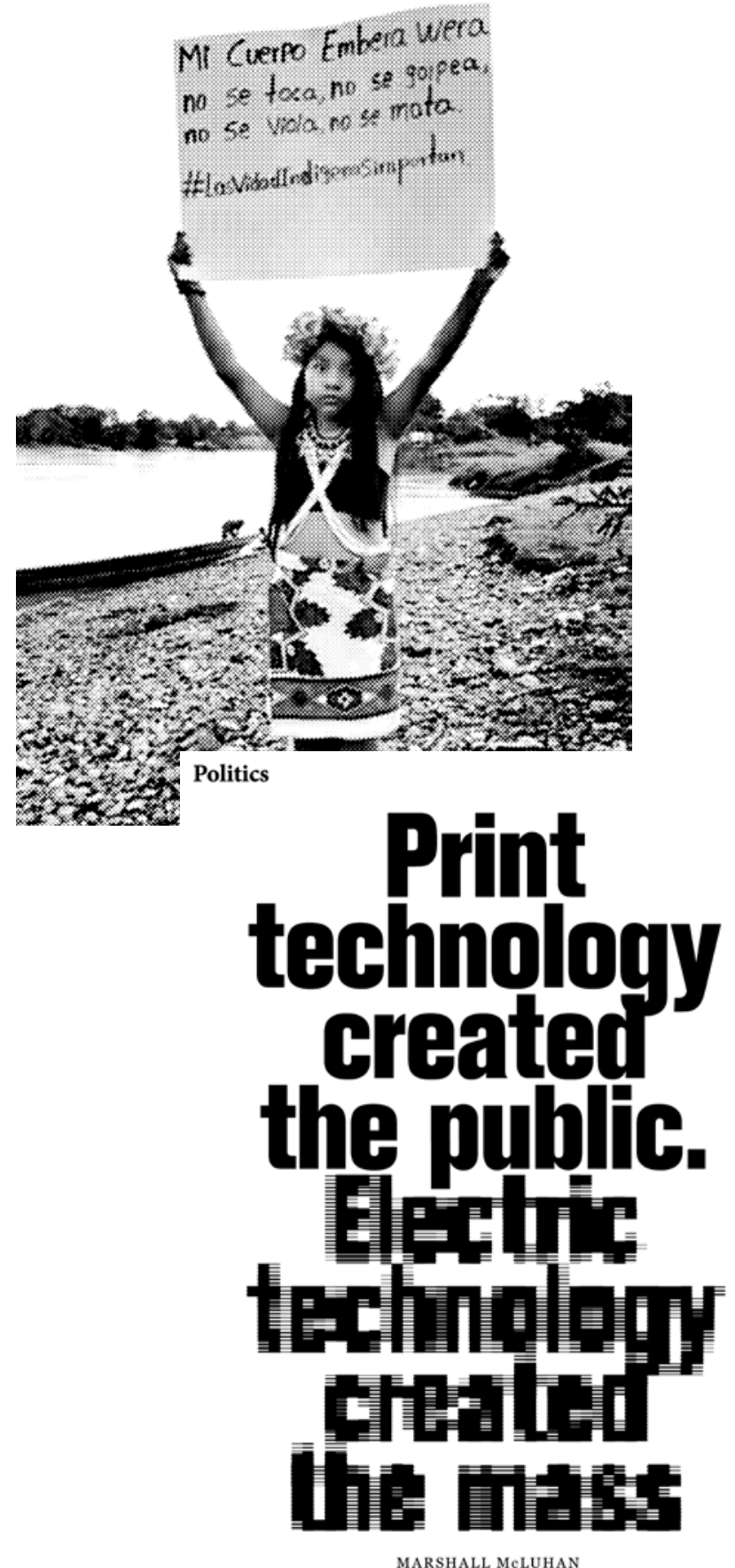

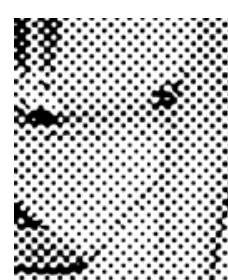
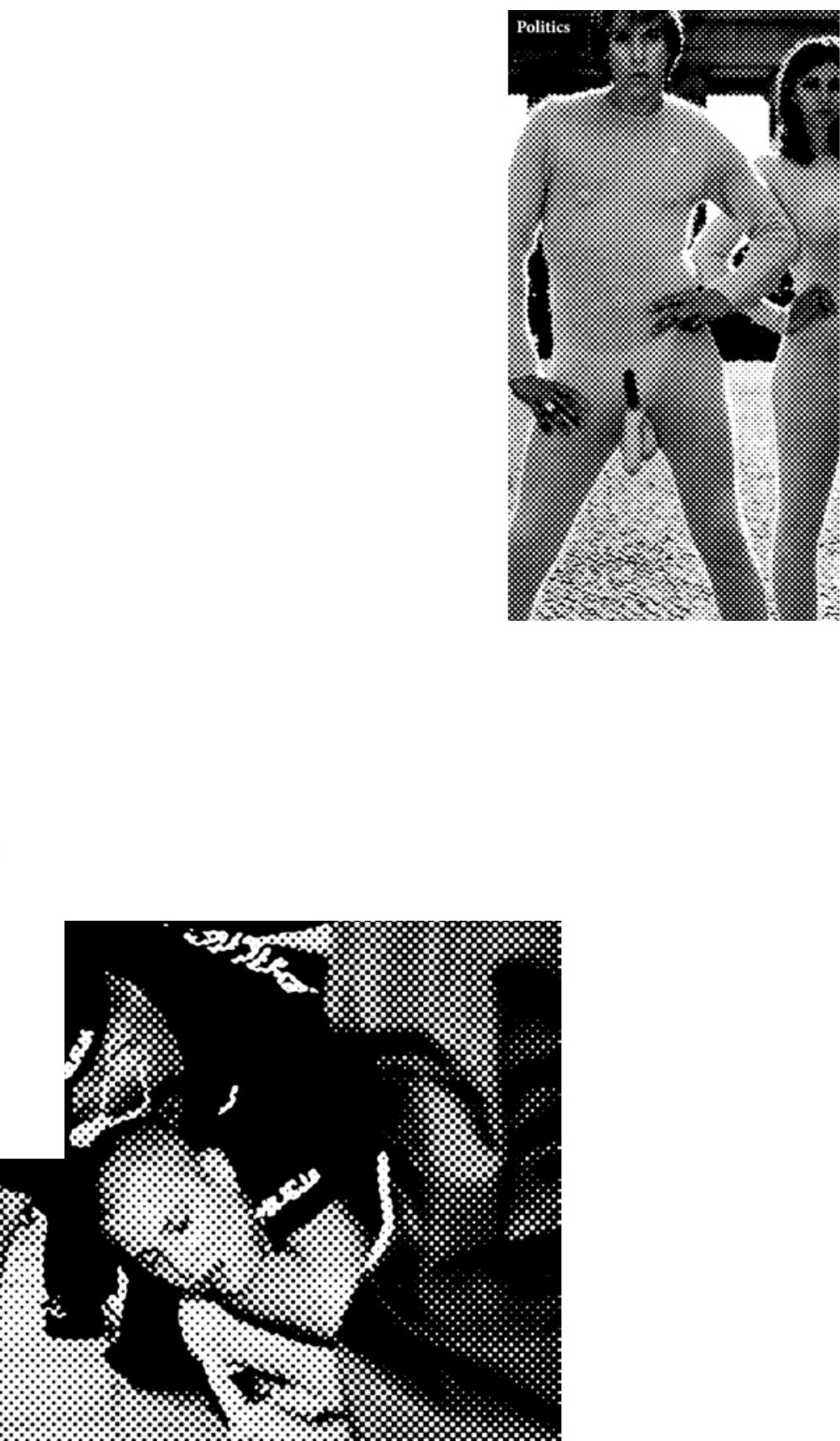
Politics
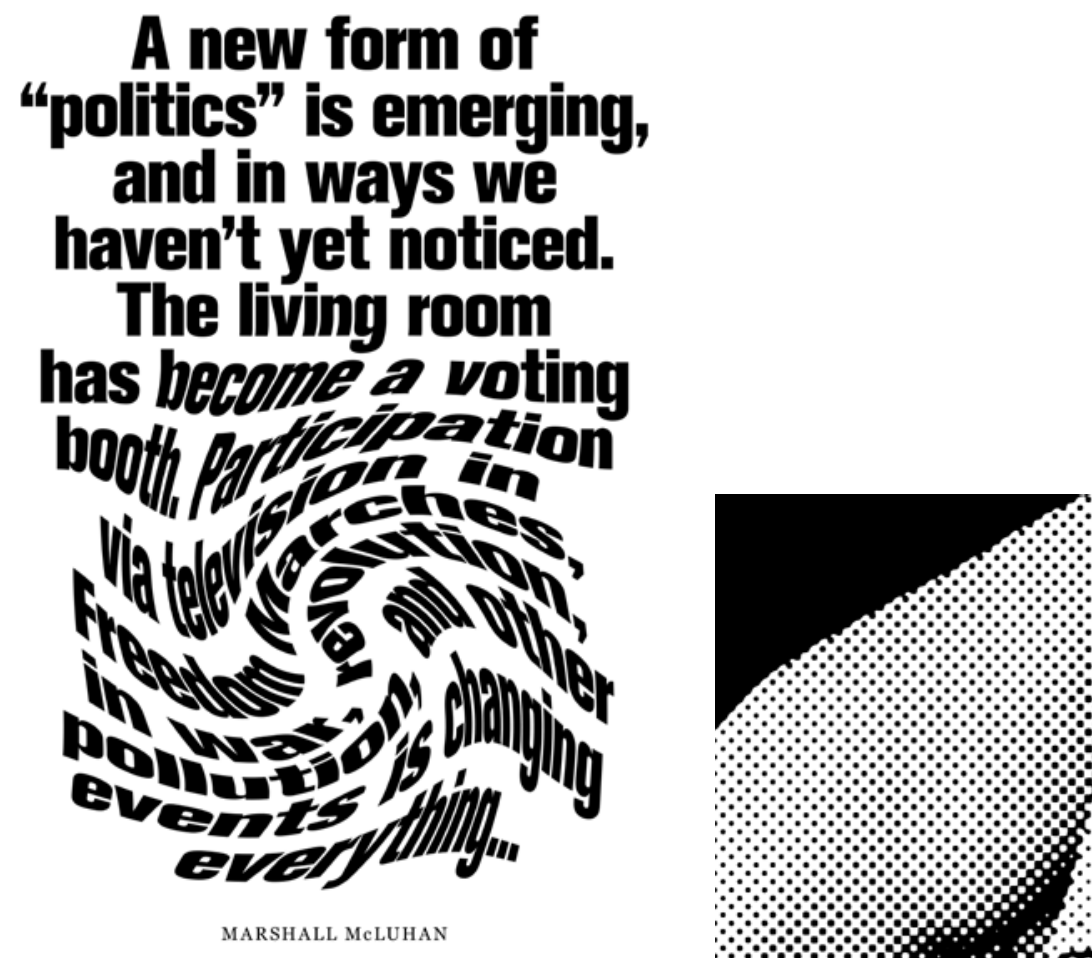

sopos
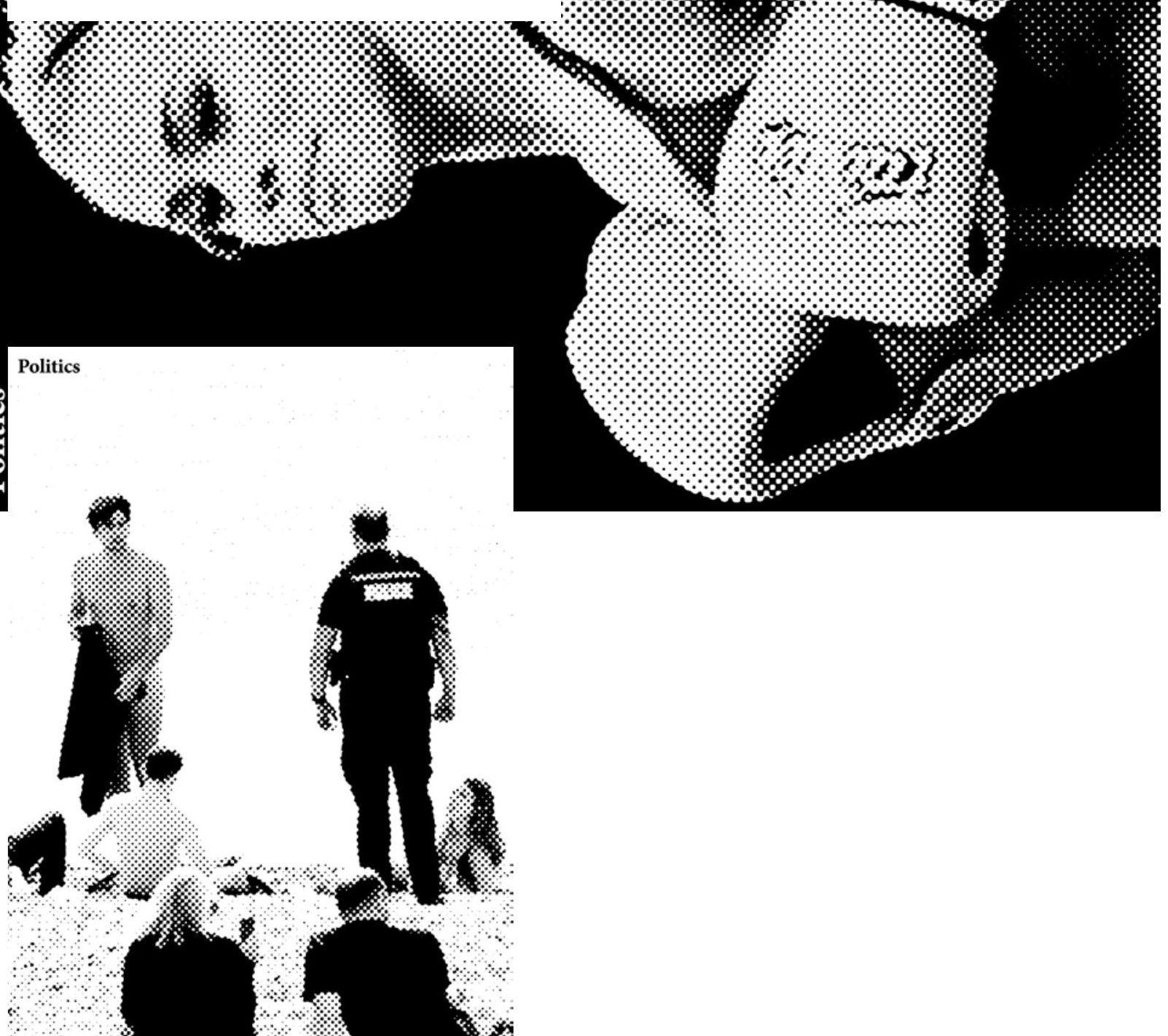


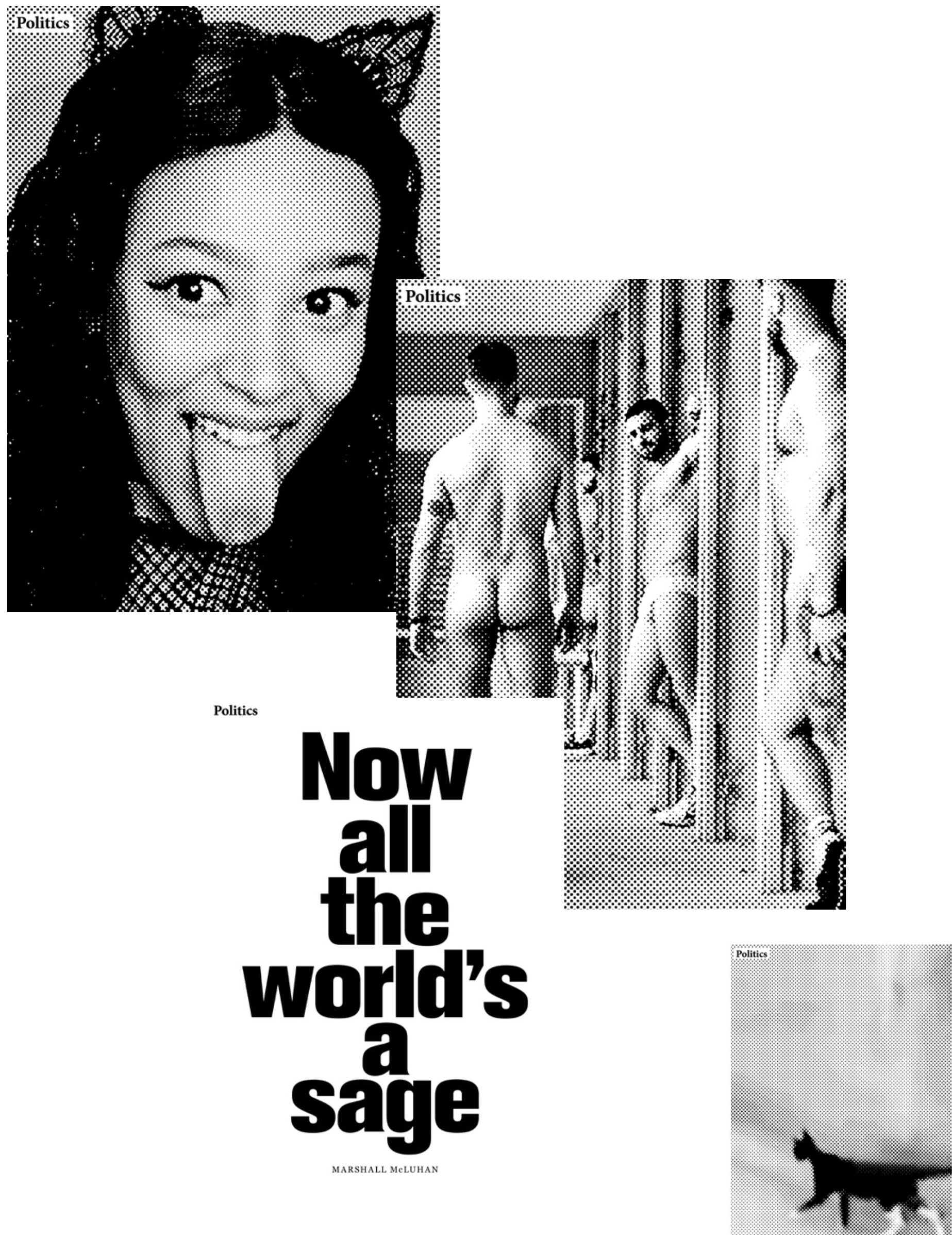

Politics 


\section{Politics}

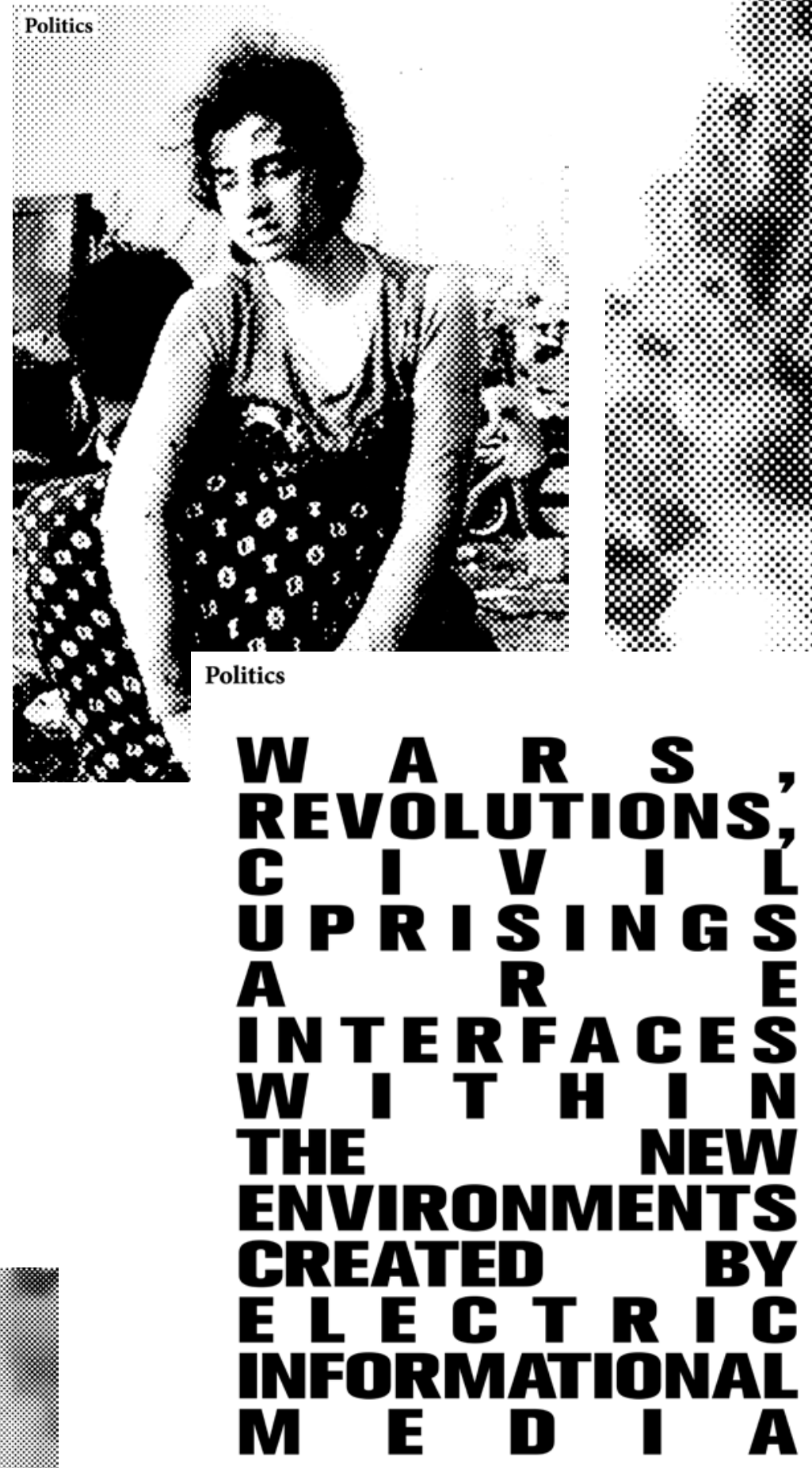

MARSHALL MCLUHAN

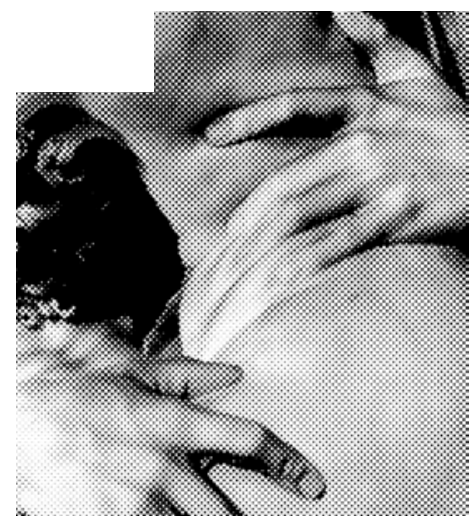




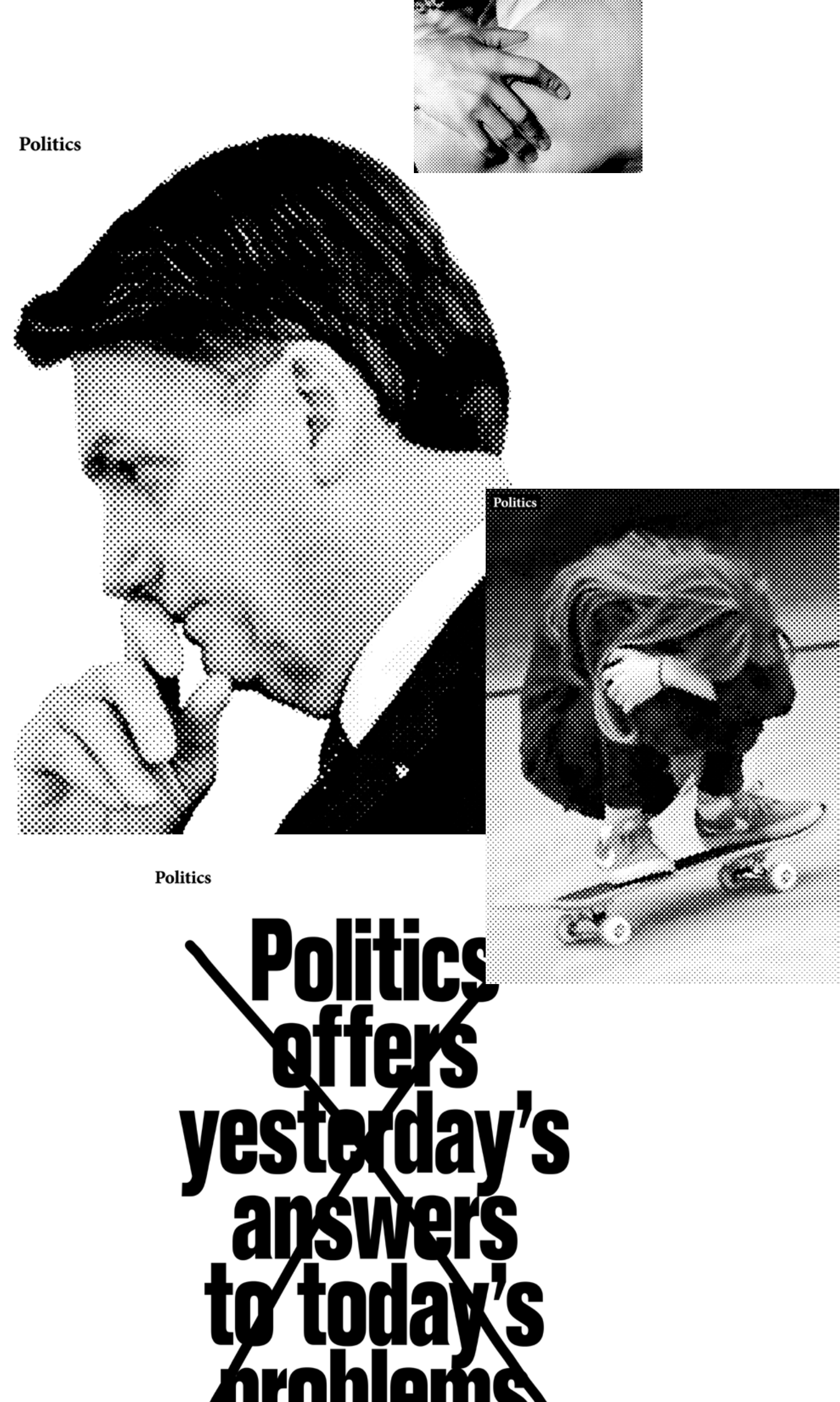




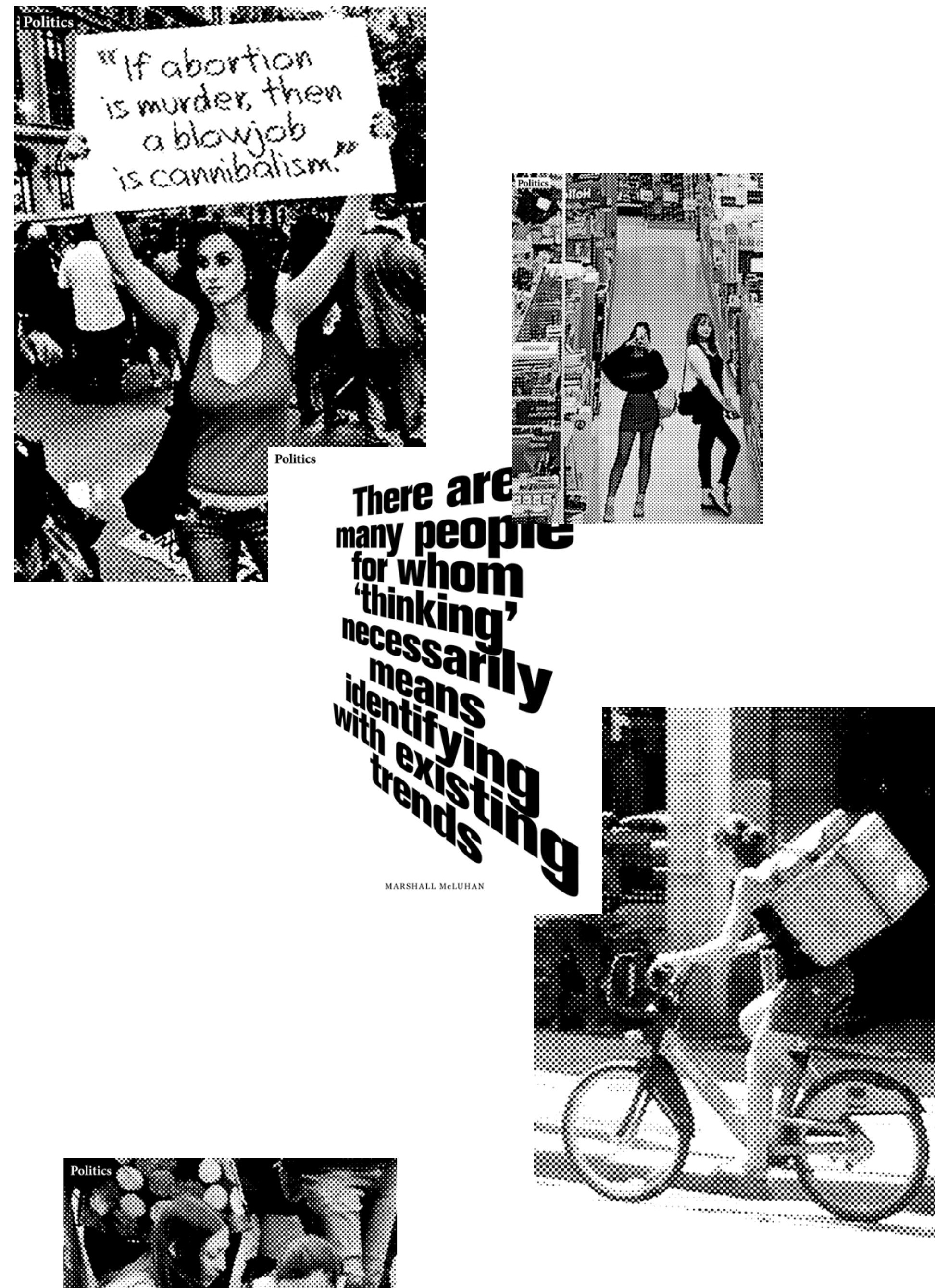




\section{Politics}
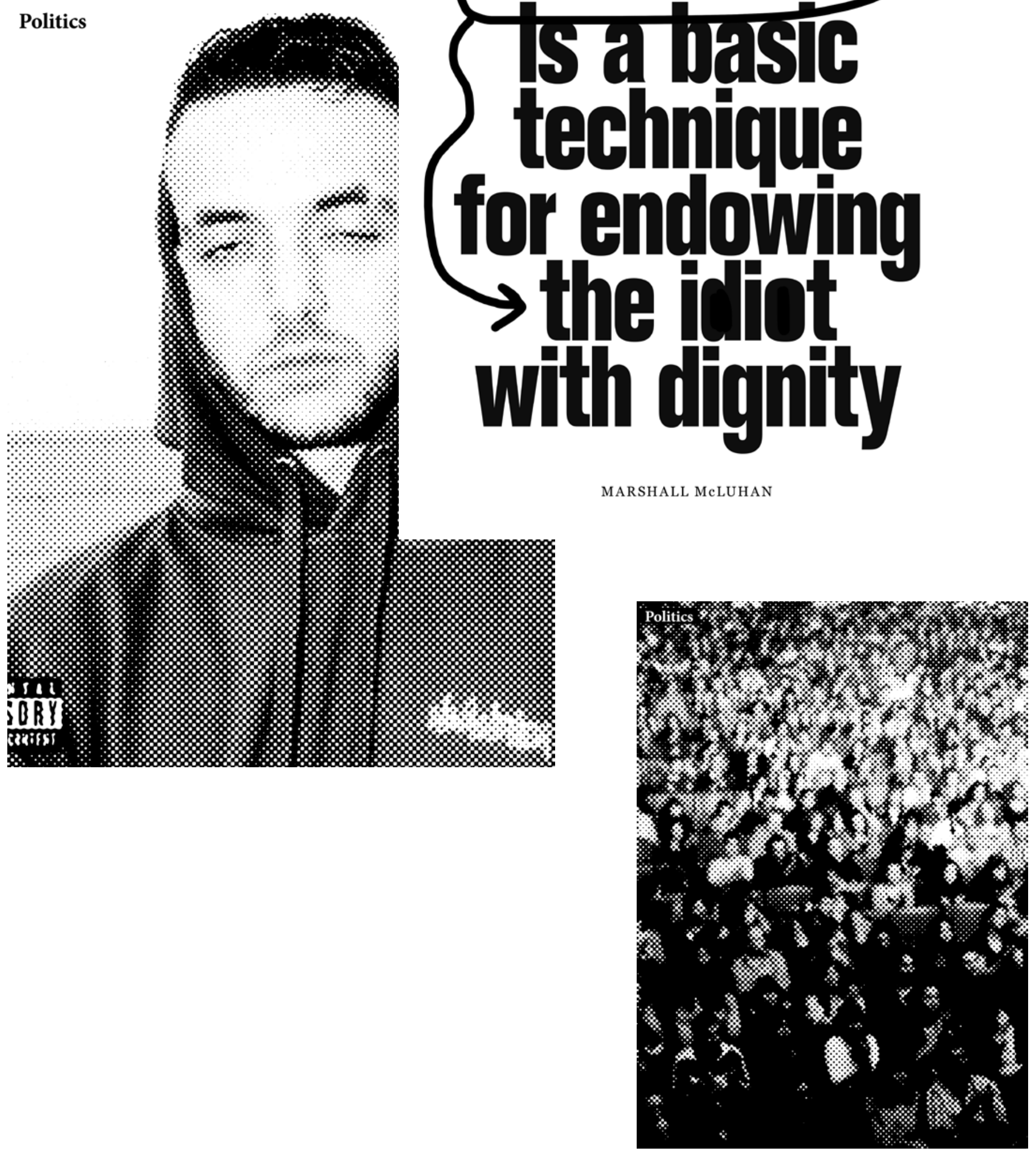


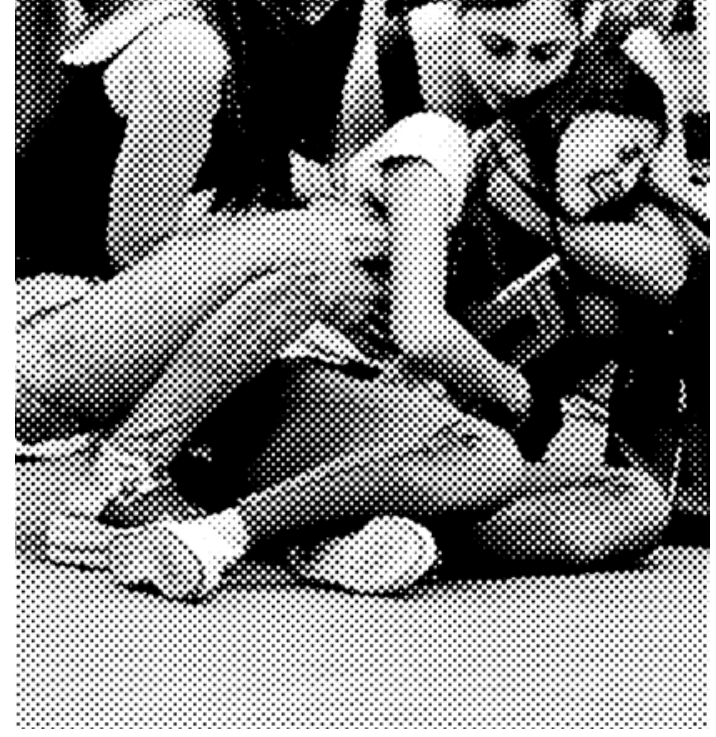

$$
\text { Politics }
$$

Politics

Politics

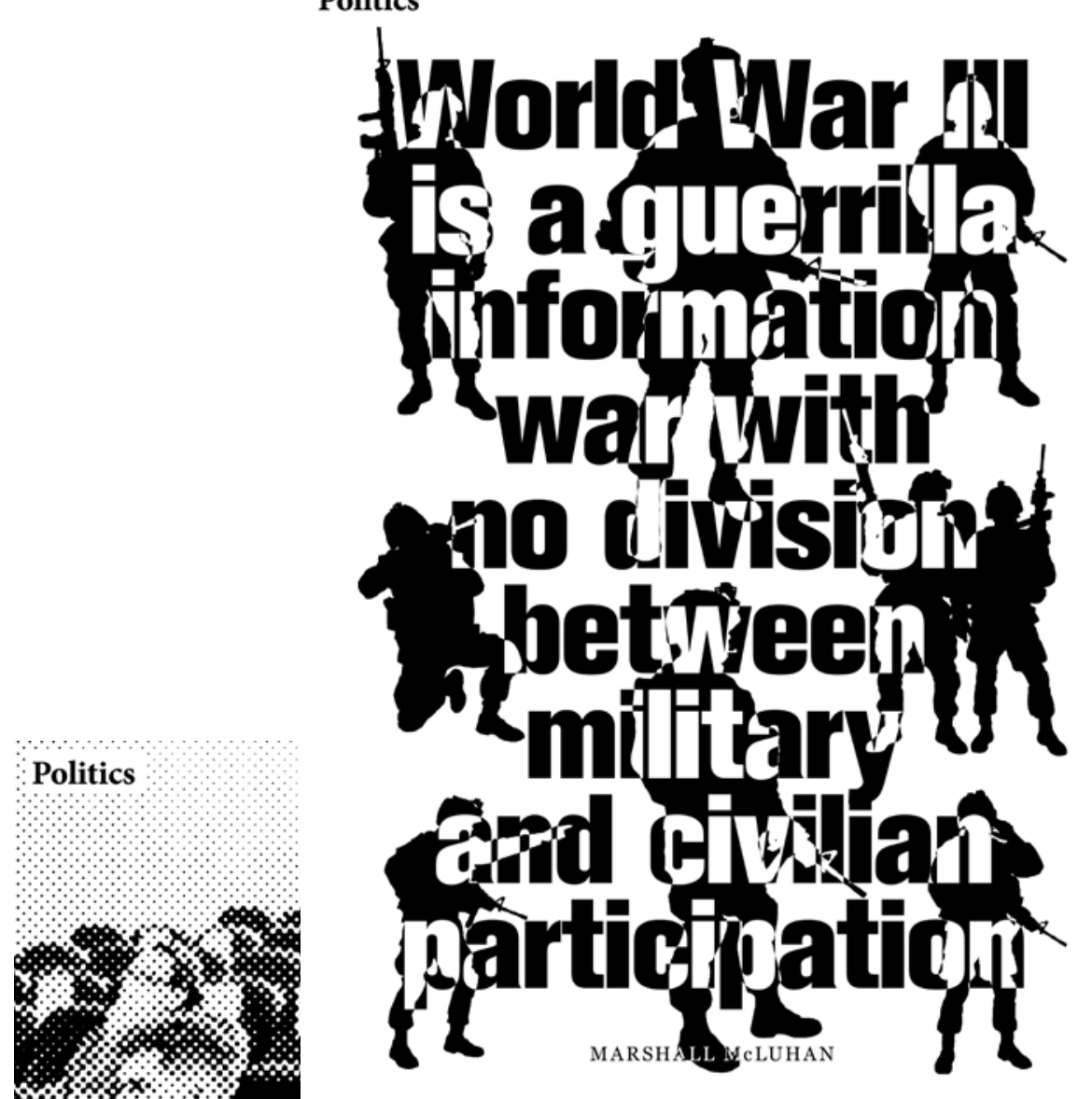

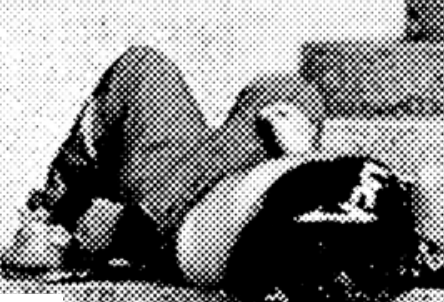
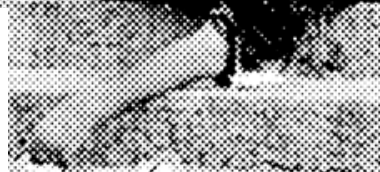

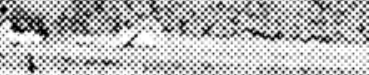

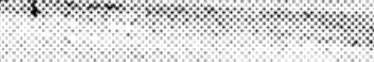



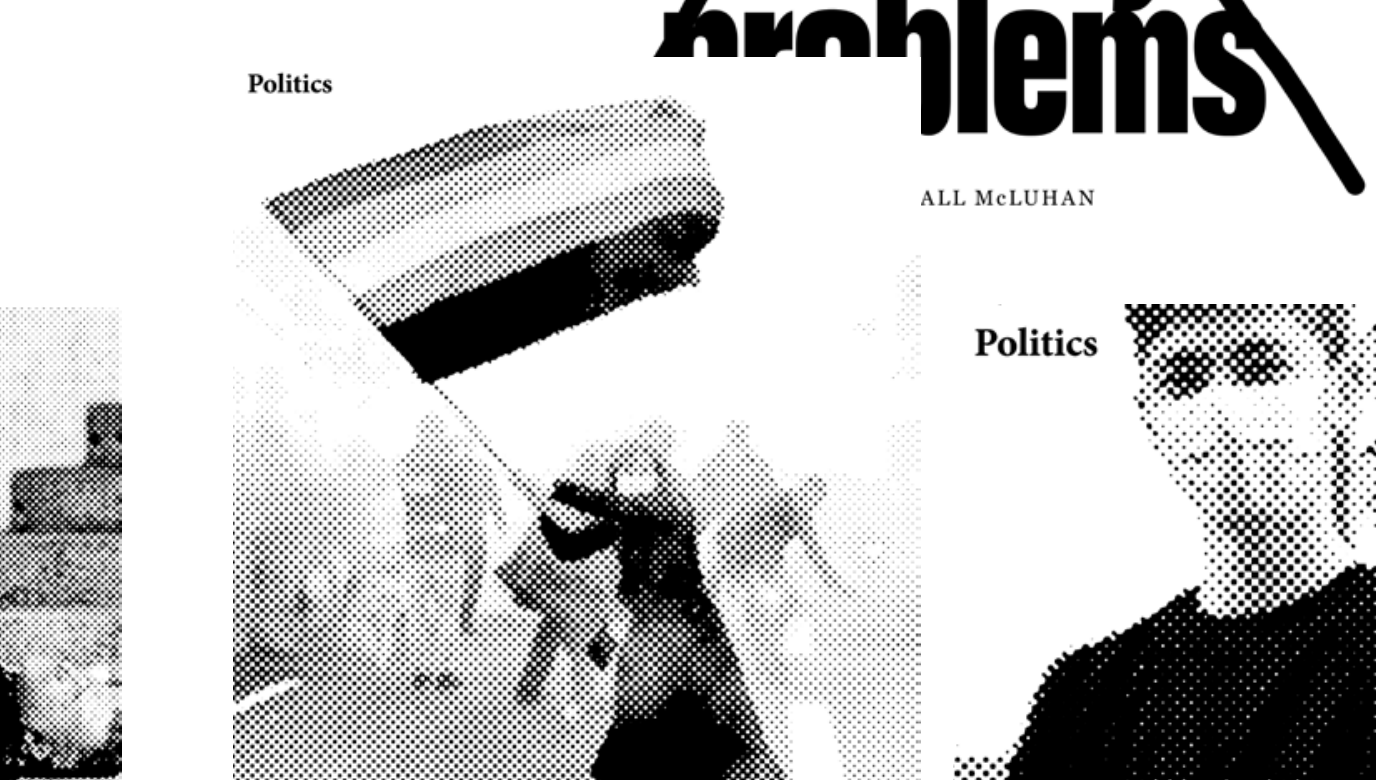

8
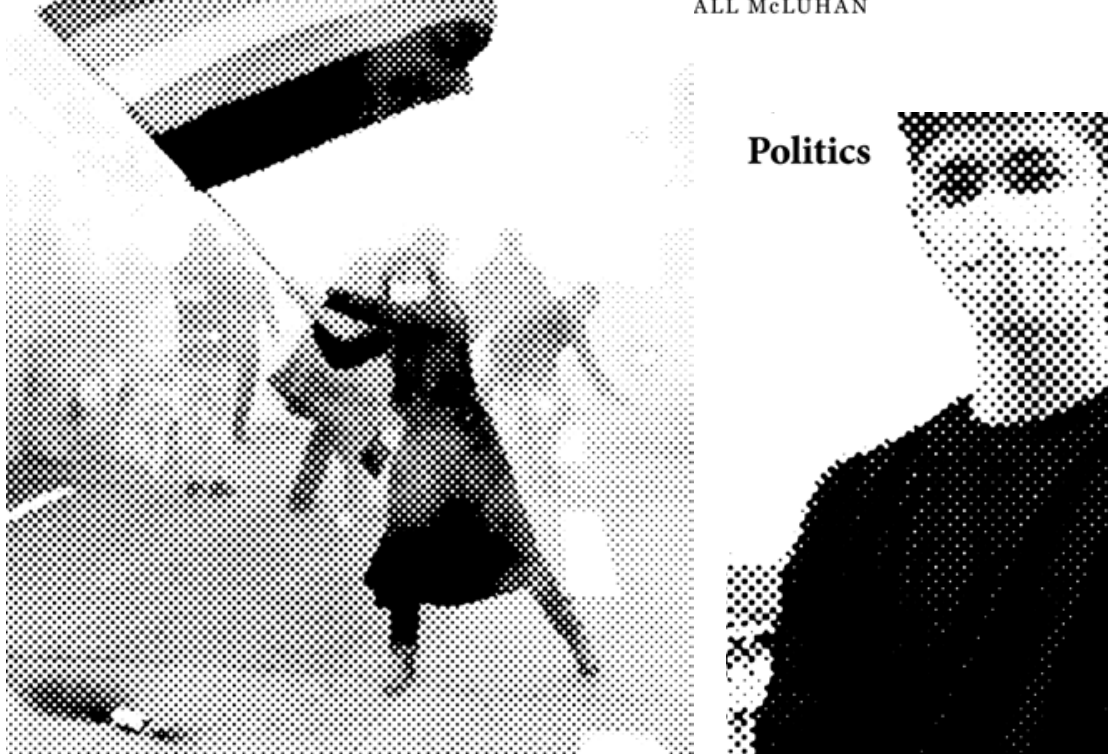

\&

२

mast

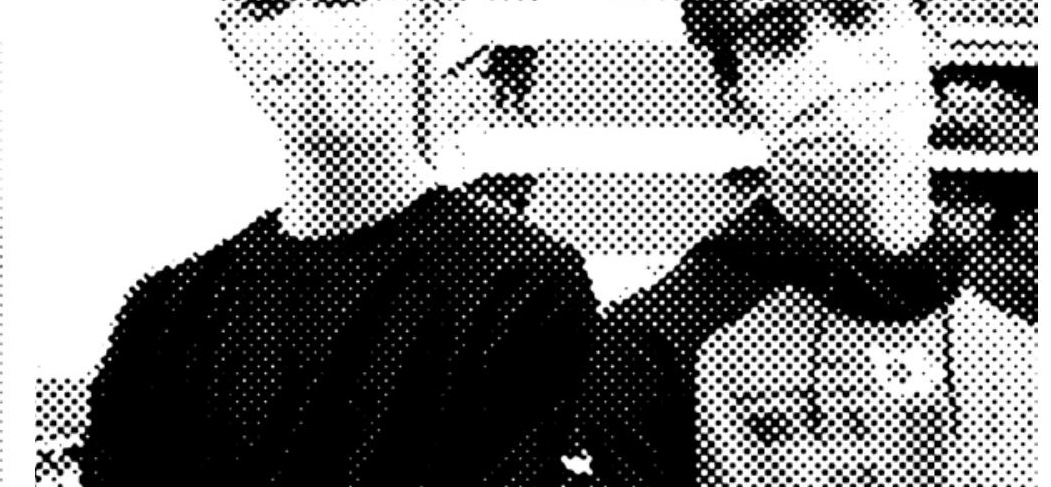

Politics
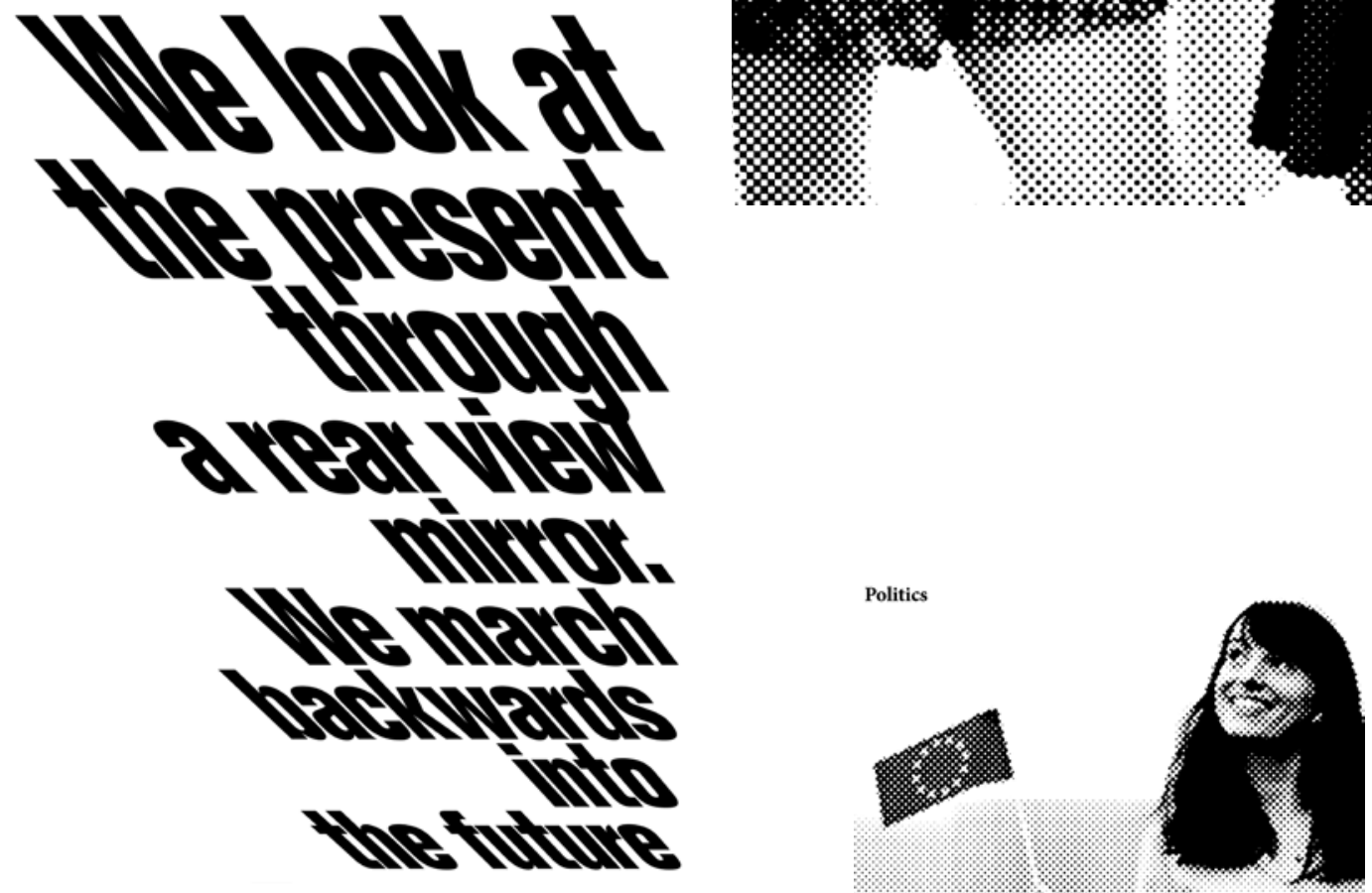

MARSHALL MCLUHAN

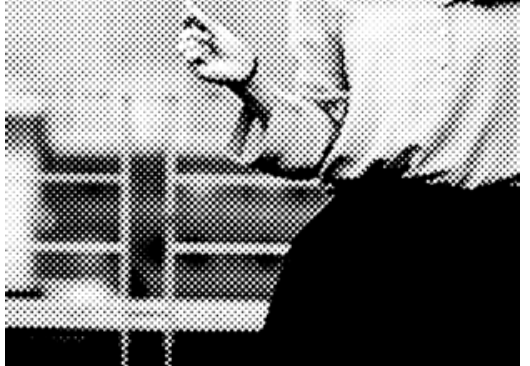


Politics

Politics

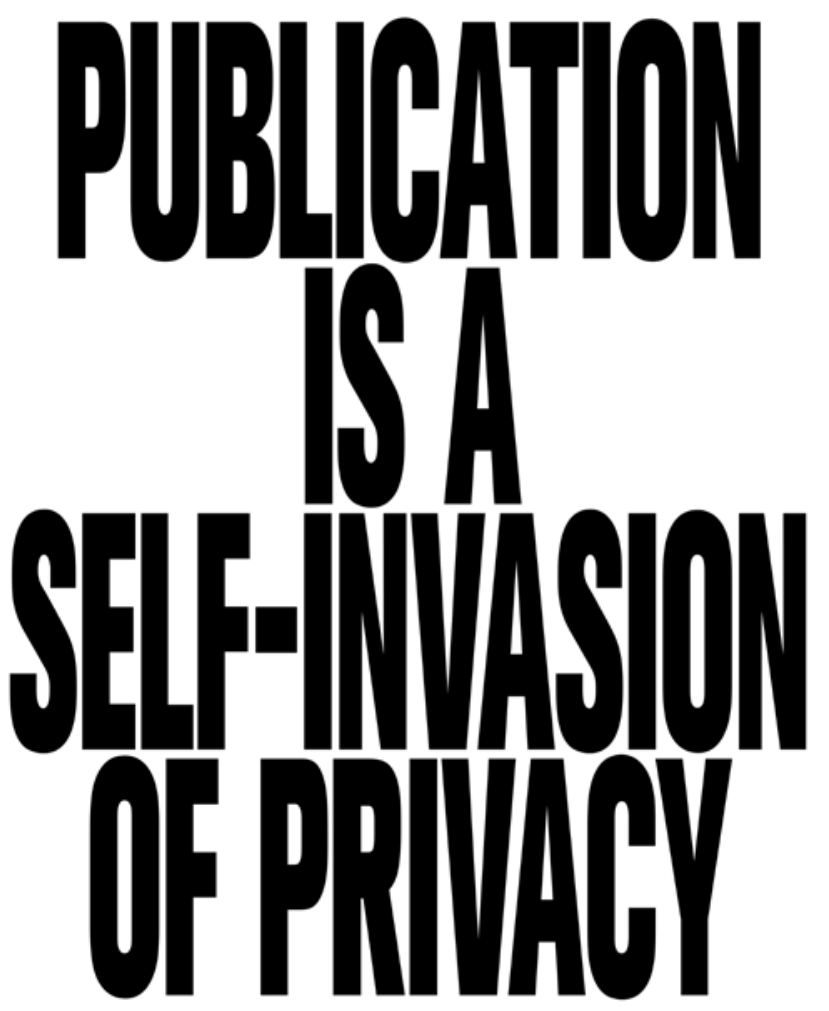

MARSHALL MCLUHAN

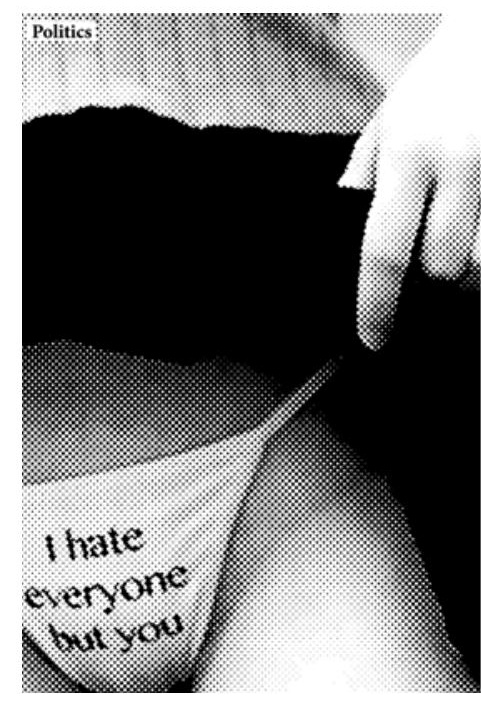

-оpeว!ןр ıәs әpәnd «qun

әъsә әр ор!ฺәџиоว 


\section{Conclusión}

Tanto McLuhan como Buck-Morss nos enseñan a ser inconformistas y así evitar los simplismos ingenuos y convencionales que provoca el pensamiento lineal. Si queremos ser críticos necesitamos adaptarnos perceptivamente a la situación de energía comunicacional actual. Lo que a primera vista parece irregular, desconectado e irracional puede que esconda un razonamiento por intervalo. El "discurso secuencial y conectado" se basa en "colocar pensamientos uno tras otro" de "forma lineal y codificada", es decir, de forma racional-visual. Sin embargo, "el razonamiento no ocurre sobre planos únicos o sobre formas continuadas y conectadas. La mente trabaja a saltos. Pone cosas juntas en toda clase de proporciones y ratios." (Sempere 1975, p.121)

Como conclusión final, esta pregunta: ¿Somos como estrellas fugaces y solitarias que cruzamos el horizonte con un plan totalmente cerrado y lineal, o más bien, formamos parte de una compleja e inabarcable constelación o galaxia cuya estructura gravitatoria nos permite interactuar con otras estrellas, planetas, materia oscura y energía creativa e imaginaria? No tenemos una respuesta definitiva, pero una cultura global que busque una acción política común necesita crear una comunidad de imágenes abiertas y compartidas que construyan una cantidad de conexiones en intervalos inagotables...

\section{Referencias}

BUCK-MORSS, S. (2013,12 de abril). Visual Studies and Global Imagination.

BUCK-MORSS, S. (2015, 17 de octubre). Seeing Global.

MCLUHAN, M. Mcluhanism. Recuperado el 4 de diciembre de 2020 en: https://www.marshallmcluhan.com/ mcluhanisms/

MCLUHAN, M. \& FIORE, Q. (2008). The Medium is the Massage. London: Penguin Design Series.

SEMPERE, P. (1975). La Galaxia McLuhan. Valencia: Fernando Torres Editor.

Nota

Todas las imágenes que aparecen en el ensayo visual pertenecen al proyecto Politics, una biblioteca abierta que consta de más de 5000 imágenes retomadas, reapropiadas y reinterpretadas de la constelación: Instagram-Tumblr-Facebook-Blogspot. 